\title{
Work readiness during COVID-19 among taxibike online drivers in Samarinda, Indonesia
}

\author{
Dina Lusiana Setyowati ${ }^{1}$, Swandari Paramita ${ }^{2}$, Riza Hayati Ifroh ${ }^{3}$, Tanti Asrianti ${ }^{4}$, Evi Fitriany ${ }^{5}$, \\ Wahnadita Rahman ${ }^{6}$ \\ ${ }^{1}$ Department of Occupational Health and Safety, Public Health Faculty, Mulawarman University, Indonesia \\ ${ }^{2,5}$ Department of Community Medicine, Medical Faculty, Mulawarman University, Indonesia \\ ${ }^{3,6}$ Departement of Health Promotion, Public Health Faculty, Mulawarman University, Indonesia \\ ${ }^{4}$ Departement Epidemiology, Public Health Faculty, Mulawarman University, Indonesia
}

\begin{tabular}{l} 
Article Info \\
\hline Article history: \\
Received Jan 30, 2021 \\
Revised May 21, 2021 \\
Accepted Jun 21, 2021 \\
\hline
\end{tabular}

Keywords:

COVID-19

Knowledge

Attitudes

Risk perception

Taxibike online

\begin{abstract}
COVID-19 caused a pandemic around the world, including in Indonesia. This greatly affected the informal business sector, such as online taxibike drivers. The success of this program to control the spread of COVID-19 is greatly influenced by knowledge, attitudes, and actions in the community. The purpose of this study was to identify behavioral factors during the pandemic. An online survey was conducted with 100 online taxibike drivers using a structured questionnaire and Google Forms. Data were analyzed using the Spearman rank test with CI of 95\%. Although most online taxibike drivers have sufficient knowledge about COVID-19, some drivers had important misconceptions about COVID-19, namely that COVID-19 is not contagious, weak immune resistance may cause them to contract COVID-19, and it is highly unlikely that they will contract COVID-19 when leaving the house without wearing a mask, and believing that handwashing with soap and using hand sanitizer will not prevent COVID-19. To address these misconceptions, interventions should be targeted to online taxibike drivers to increase their health education and literacy regarding the urgency of preventing COVID-19. It is also important to consider incorporating both interpersonal approaches and conventional and digital-based groups when encouraging changes in their attitudes and practices towards COVID-19.
\end{abstract}

This is an open access article under the $C$ C BY-SA license.

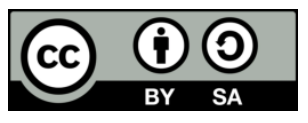

\section{Corresponding Author:}

Dina Lusiana Setyowati

Department Departement of Occupational Health and Safety

Public Health Faculty, Mulawarman University

Sambaliung Road, Gunung Kelua Campus, Samarinda, East Kalimantan, Indonesia

Email: dinalusiana@fkm.unmul.ac.id

\section{INTRODUCTION}

COVID-19 is a disease caused by the SARS-COV-2 novel coronavirus, which was first discovered in Wuhan, China in December 2019. The virus spread so rapidly throughout the world that the World Health Organization (WHO) declared it a pandemic. According to data from the WHO, as of August 24, 2020, 23,311,719 confirmed cases were recorded with 806,410 deaths due to COVID-19 [1]. In Indonesia, the number of confirmed cases based on data from the COVID-19 Handling Task Force website page as of August 25, 2020 reported 157,859 cases with a death toll of 6,858 cases [2]. East Kalimantan also contributed to the number of confirmed COVID-19 cases as of the same date with 3,145 cases and a death toll of 125 cases. As the capital of East Kalimantan Province, Samarinda City, Indonesia is the second- 
highest contributor after Balikpapan City of COVID-19 cases; as of August 25, 2020, there were 672 cases with 26 deaths [3].

The COVID-19 outbreak has affected daily life in countries around the world, including Indonesia. Policies aimed at preventing the spread of COVID-19 in the form of lockdowns or the implementation of Large-Scale Social Restrictions has a domino effect, especially in business sectors that offer services that make it impossible to implement a work-from-home system. One of the service sectors affected is the automotive industry and its derivatives. Like the online ojek business (more commonly referred to as ojol), grab drivers in Malang Raya reported their income has decreased [4]. The online motorcycle taxi is a form of transportation that offers passenger delivery, food ordering, and delivery of goods with high mobility. Drivers are a risk group for transmitting or contracting COVID-19, and, therefore, their knowledge and perceptions of the risk and dangers of COVID-19 will affect efforts to prevent this disease. Shidiqi et al. [5] showed that gojek drivers $47.3 \%$ did not apply health protocols, namely not wearing personal protective equipment (PPE), such as masks, glasses, covering helmet glasses, and carrying hand sanitizer, which increased the risk of spreading the virus.

The WHO's strategic prepare and strategic preparedness and response plan aims to protect countries with weak health systems. Its goals are to limit transmission, provide early treatment, communicate key information, and minimize social and economic impacts. Besides, the WHO is focused on developing diagnostics that are easy to implement, accelerating existing vaccine candidates, and preventing infection. The rate of transmission of the COVID-19 outbreak is not sufficiently inhibited by medical intervention. Vaccine and drug research still takes a long time and is only now entering clinical trials, so non-medical engineering in the form of social interventions must be implemented to prevent the spread of COVID-19 [1].

The Indonesian government has established a policy to provide public protection by implementing health protocols, namely using masks, washing hands with soap or using hand sanitizer, and avoiding crowds. Prevention and control of COVID-19 must be carried out at global, national, and community levels so that with a limited number of health workers, the spearhead of this program is public compliance in complying with health protocols. Notably, lessons have been learned from the severe acute respiratory syndrome (SARS) outbreak that occurred. During the SARS outbreak, non-pharmaceutical interventions were also carried out in the form of quarantine and hygiene measures, which greatly helped control the SARS outbreak [6]. Based on previous research, it is known that the success of this social intervention depends on people's behaviour [7], [8]. Public adherence to management strategies is needed to combat the transmission of COVID-19, which is influenced by their knowledge, attitudes, and practices towards COVID-19 [9]. For instance, the perceptions and behavior of students in China have been shown to affect the spread of the pandemic [10], and sufficient knowledge about COVID-19 infection and aspects of its prevention as well as attitudes towards COVID-19 has been related to the willingness of the public to follow guidelines on quarantine and social distancing in India [11]. Several studies have been conducted regarding knowledge, attitudes, and practices among health workers, students, and the public, but no research has focused on online motorcycle taxi drivers during the pandemic. Online motorcycle taxi drivers are part of the community who are at risk of contracting COVID-19. Besides, the risk perception of the dangers of COVID-19 among this population has yet to be explored. Perception is the main component in changing a person's or society's behavior. Brewer et al. explained risk perception is a central construct in many behavioral theories and is referred to as the level of harm that the hazard would pose and the perceived vulnerability (often also described as the perceived likelihood or perception of such risk) [12]. Thus, it is not enough to identify and analyze knowledge, attitudes, and behavior in the community but aspects of risk perception also need to be considered because this will help provide important information for prevention strategies, namely changing misconceptions about COVID-19 and health promotion programs to increase public awareness. It is hoped that changes in people's behavior in adhering to health protocols can become collective habits in the community. This is also supported by previous research that the perception factor is an individual and personal part that needs to be improved (public risk perception) so that the adopted behavior is more durable [13]. Therefore, the purpose of this study was to identify and explore the knowledge, attitudes, and perceptions of the risk of COVID-19 transmission and the perception of prevention of COVID-19 during the pandemic among online motorcycle taxi drivers in Samarinda, Kalimantan East, Indonesia.

\section{RESEARCH METHOD}

This research was conducted with integrity and ethical principles that are generally accepted and approved by the Ethics Committee of the Faculty of Medicine, Mulawarman University (No. 45/KEKP-FK/ $\mathrm{XI} / 2020$ ). An informed consent statement was provided on the first page of the questionnaire before the collection of research data. Informed consent was obtained automatically after the respondent completed the online survey. 
This research was an observational study with a cross-sectional approach conducted with online motorcycle taxi drivers in Samarinda, Indonesia. We used a structured questionnaire using Google Forms accompanied by informed consent sent via WhatsApp to the respondent's contact. This WhatsApp application is widely used by respondents, and they were asked to forward the link to other online motorcycle taxi drivers. When receiving and clicking on the link obtained, the online motorcycle taxi driver was automatically provided with information about the research and informed consent. After online motorcycle taxi drivers decided to participate in this study, they filled in their demographic details of age, gender, education level, religion, marital status, and employment status. Next, several questions appeared in sequence, which the respondents must answer. Data were collected from November 6-10, 2020.

The population for this study was 1,500 online motorcycle taxi drivers. Sampling was conducted using quota sampling to obtain 125 samples. Of the 125 samples that were planned, only 100 agreed to complete the questionnaire and a rapid COVID-19 test. The justification for selecting this sample is based on the high level of mobilization and the number of online orders per day according to the data and information from online driver agency. The other 25 stated they were not willing to participate because they were afraid of testing positive, which would mean they would have to self-isolate and could not work. They were also afraid this would lead to stigma from the community or fellow online motorcycle taxi drivers.

The questionnaire was developed by the researchers and contained four sections about knowledge about COVID-19, perceptions of risk of transmission, risk of prevention, and attitudes about COVID-19 during the pandemic. Four questions related to knowledge were scored on a 4-point Likert scale ( $1=$ do not know at all to 4=many know) and four questions related to perceptions of risk were scored on a 5-point Likert scale $(1=$ strongly disagree to $5=$ strongly agree). Four items related to attitudes and three items related perception of the risk of COVID-19 transmission were assessed on a 4-point Likert scale (1=not bad to $4=$ awfully). Perceptions of the prevention of transmission of COVID-19 were related to health protocol indicators, namely trust in washing hands with soap and using hand sanitizer, physical distancing, wearing masks, and staying at home. The research data were analyzed using descriptive statistics and the Spearman rank test with a significance level of $95 \%$.

\section{RESULTS AND DISCUSSION}

\subsection{Descriptive variable score}

Table 1 describes the scores obtained from the 100 respondents. For the knowledge variable, scores ranged from 12 to 23 out of 24 with an average score of 19.38 ( $\mathrm{SD}=2.00)$. For the attitude variable, scores ranged from 6 to 16 with an average score of $12.28(\mathrm{SD}=2.17)$. For the variable of risk perception of COVID-19 transmission, the lowest value was 14 and the highest was 32 with an average of 23.17 $(\mathrm{SD}=4.14)$. For the perception variable of COVID-19 prevention, the minimum score was 14 and the maximum was 23 , with an average of $20.68(\mathrm{SD}=1.71)$.

Table 1. Descriptive variable score

\begin{tabular}{lcccc}
\hline \multicolumn{1}{c}{ Variable $(\mathrm{n}=100)$} & Highest score & Lowest score & Maximum score & Mean \pm SD \\
\hline Knowledge & 24 & 12 & 23 & $19.38 \pm 2.00$ \\
Attitude & 16 & 6 & 16 & $12.28 \pm 2.17$ \\
Perceptions of the risk of transmission of COVID-19 & 32 & 13 & 32 & $23.17 \pm 4.14$ \\
Perceptions of COVID-19 prevention & 24 & 14 & 23 & $20.68 \pm 1.71$ \\
\hline
\end{tabular}

\subsection{Characteristic of respondents}

Table 2 illustrates that the average age of the respondents was 35.23 years ( $\mathrm{SD}=6.2$ ), and most of the respondents were male $(86 \%)$. More than half of the respondents $(69 \%)$ were married. In terms of religious affiliation, most identified as Muslims (93\%) with the remaining (7\%) identifying as Christians (Catholic or Protestant). Online motorcycle taxi driver was the main occupation of most respondents $(81 \%)$ with the remaining $(19 \%)$ stating it was a side job. In terms of education, more than half of the respondents $(72 \%)$ had attained senior high school/equivalent and $2 \%$ only had elementary education. A small percentage of respondents $(7 \%)$ acknowledged physical contact with patients under surveillance in the last 14 days. The distribution of respondent characteristics based on demographics, which is presented in the Table 2. 
Table 2. Descriptive statistics based on demographics and experience in the last 14 days physical contact with patient under supervision (PDP)

\begin{tabular}{|c|c|}
\hline Variable & $\%$ \\
\hline Age (Year), M \pm SD & $35.23 \pm 9.5$ \\
\hline \multicolumn{2}{|l|}{ Gender, n $(\%)$} \\
\hline Men & $86(86)$ \\
\hline Women & $14(14)$ \\
\hline \multicolumn{2}{|l|}{ Marital status } \\
\hline Not Yet/Not married & $31(31)$ \\
\hline Married & $69(69)$ \\
\hline \multicolumn{2}{|l|}{ Relegion } \\
\hline Muslims & $93(93)$ \\
\hline Catholic & $2(2)$ \\
\hline Protestan & $5(5)$ \\
\hline \multicolumn{2}{|l|}{ Job status as an online driver } \\
\hline Secondary & $19(19)$ \\
\hline Primer & $81(81)$ \\
\hline \multicolumn{2}{|l|}{ Education } \\
\hline Elementary school/equivalent & $2(2)$ \\
\hline Junior high school/equivalent & $10(10)$ \\
\hline Senior high school/equivalent & $72(72)$ \\
\hline Diploma/Bachelor degree & $16(16)$ \\
\hline \multicolumn{2}{|c|}{ Experience 14 days, there is physical contact with PDP } \\
\hline No & $82(82)$ \\
\hline Yes & $7(7)$ \\
\hline Do not know & $11(11)$ \\
\hline
\end{tabular}

\subsection{Knowledge of COVID-19, nature of transmission and victims}

Table 3 illustrates that half of the respondents had sufficient knowledge about COVID-19, but a small percentage (5\%) reported not knowing anything about COVID-19. Regarding knowledge about the nature of COVID-19 transmission, more than half of the respondents said it was very contagious (63\%), 26\% answered that it was quite contagious, and 2\% said that COVID-19 is not contagious.

As much as $54 \%$ of respondents thought that COVID-19 was transmitted quite quickly after contact with sufferers, and 20\% believed that COVID-19 transmission could occur right away. However, as much as $5 \%$ of respondents answered that the transmission of COVID-19 took months. Just over half (53\%) of the online motorcycle taxi drivers said all victims of COVID-19 have been counted.

Table 3. Knowledge of COVID-19 in general, the nature of transmission and the number of victims

\begin{tabular}{|c|c|c|c|c|}
\hline Question & \multicolumn{4}{|c|}{ Answer (\%) } \\
\hline $\begin{array}{l}\text { In your opinion, what is your level of } \\
\text { knowledge about COVID-19? }\end{array}$ & $\begin{array}{l}\text { Do not know at all } \\
\text { (5) }\end{array}$ & $\begin{array}{l}\text { Little to know } \\
(30)\end{array}$ & $\begin{array}{l}\text { Know enough } \\
(50)\end{array}$ & Many know (15) \\
\hline $\begin{array}{l}\text { In your opinion, what is the nature of the } \\
\text { transmission of COVID-19? }\end{array}$ & Not contagious (2) & $\begin{array}{l}\text { Slightly } \\
\text { contagious (9) }\end{array}$ & $\begin{array}{l}\text { Moderately } \\
\text { contagious (26) }\end{array}$ & $\begin{array}{l}\text { Very contagious } \\
(63)\end{array}$ \\
\hline $\begin{array}{l}\text { In your opinion, how fast is COVID-19 } \\
\text { transmitted after contact with someone with } \\
\text { COVID-19? }\end{array}$ & $\begin{array}{l}\text { Very long, in a } \\
\text { matter of months } \\
\text { (5) }\end{array}$ & $\begin{array}{l}\text { It takes weeks } \\
(21)\end{array}$ & Pretty fast (54) & Right then (20) \\
\hline $\begin{array}{l}\text { What do you think about the victim from } \\
\text { COVID-19? }\end{array}$ & $\begin{array}{l}\text { Very few victims } \\
\text { (4) }\end{array}$ & $\begin{array}{l}\text { A small number } \\
\text { of victims (1) }\end{array}$ & $\begin{array}{l}\text { A large number of } \\
\text { victims (42) }\end{array}$ & $\begin{array}{l}\text { Very large number } \\
\text { of victims (53) }\end{array}$ \\
\hline
\end{tabular}

\subsection{Information sources, socialization, reduction risk and mechanism of transmission COVID-19}

Table 4 provides information that the source of media information most used by respondents was social media (19\%), and some respondents used more than three media sources, including online news, social media, television, and information from other people. Most respondents (81\%) said they had seen appeals, circulars and banners about COVID-19 in their home environment, but 19\% stated they had not seen any such information in their home environment. Regarding knowledge of the causes of COVID-19, almost all online drivers (96\%) knew that the cause of COVID-19 is a virus, although $4 \%$ answered bacteria.

Most of the online drivers (85\%) said that COVID-19 was an emerging disease and a small proportion $(15 \%)$ of respondents said COVID-19 was a disease that had been around for a long time. When asked about ways to reduce risk and transmission mechanisms of COVID-19, most respondents answered a combination of more than three methods was ideal, namely washing hands, using masks, maintaining physical distance, staying at home, exercising at home, and consuming nutritious food. Regarding the transmission mechanism of COVID-19, almost half (41\%) of respondents answered that droplets and 
contaminated surfaces can transmit COVID-19; however, some agreed with incorrect statements, namely that foodborne and waterborne are transmission mechanisms.

Table 4. Information sources, socialization, reduction risk and mechanism of transmission COVID-19

\begin{tabular}{|c|c|}
\hline Question & $(\%)$ \\
\hline \multicolumn{2}{|l|}{ Sources of media information about COVID-19? } \\
\hline \multicolumn{2}{|l|}{ 1-2 Media } \\
\hline Online news & 9 \\
\hline Social media & 19 \\
\hline Information from other people & 1 \\
\hline Television & 9 \\
\hline Social media and television & 12 \\
\hline Television and Information from others & 1 \\
\hline Social media and information from others & 2 \\
\hline \multicolumn{2}{|l|}{$\geq 3$ Media } \\
\hline Online news, social media, television, information from others & 13 \\
\hline Online news, social media, television & 13 \\
\hline Online news, social media, information from others & 12 \\
\hline Online news, television, print newspapers, information from others & 8 \\
\hline Social media, television and others & 1 \\
\hline \multicolumn{2}{|l|}{ Is there any outreach (appeal, circular, a banner about COVID-19 in your Neighborhood Units/Residents? } \\
\hline Yes & 81 \\
\hline No & 19 \\
\hline \multicolumn{2}{|l|}{ In your opinion, what causes COVID-19? } \\
\hline Virus & 96 \\
\hline Bacteria & 4 \\
\hline \multicolumn{2}{|l|}{ In your opinion, is COVID-19 a disease that is emerging for the first time or not? } \\
\hline Emerging disease & 85 \\
\hline Long-standing disease & 15 \\
\hline \multicolumn{2}{|l|}{ How do you think you can reduce the risk of contracting COVID-19? } \\
\hline \multicolumn{2}{|l|}{ 1-2 Ways } \\
\hline Using a mask & 5 \\
\hline Keep physical distance, stay home & 3 \\
\hline Wash your hands, consume nutritious foods & 7 \\
\hline Wash hands, use a mask & 4 \\
\hline \multicolumn{2}{|l|}{$\geq 3$ Ways } \\
\hline Wash your hands, use a mask, keep physical distance & 30 \\
\hline Wash your hands, use a mask, keep physical distance, consume nutritious foods & 11 \\
\hline Wash your hands, use a mask, maintain physical distance, consume nutritious food, exercise at home, stay at home & 11 \\
\hline $\begin{array}{l}\text { Washing hands, wearing masks, keeping physical distance, staying at home, exercising in the house, consuming nutritious } \\
\text { food }\end{array}$ & 29 \\
\hline \multicolumn{2}{|l|}{ In your opinion, what is the mechanism of transmission of COVID-19? } \\
\hline \multicolumn{2}{|l|}{ 1-2 Mechanisms } \\
\hline Droplet & 24 \\
\hline Droplet and through food (foodborne) & 3 \\
\hline Drops and contaminated surface & 41 \\
\hline Contaminated surface & 6 \\
\hline \multicolumn{2}{|l|}{$\geq 3$ Mekanisme } \\
\hline Droplets, contaminated surface, borne water, animal bites & 9 \\
\hline Droplets, contaminated surface, foodborne and waterborne & 13 \\
\hline Droplets, contaminated surface, foodborne, waterborne, and animal bites & 4 \\
\hline
\end{tabular}

\subsection{Attitudes toward COVID-19}

Table 5 shows that $36 \%$ of respondents believed COVID-19 is awfully severe, $36 \%$ believed it is severe, whereas $15 \%$ and $2 \%$ believed it is slightly severe and not severe, respectively. Most respondents perceived the risk of COVID-19 transmission to be serious or very serious. However, $15 \%$ of respondents said they were very unprepared to face this risk. Although most drivers felt prepared, $36 \%$ said they were afraid of contracting COVID-19 and 34\% were very afraid. The distribution of respondent characteristics based on questions about attitudes towards COVID-19 a shown in Table 5.

\subsection{Perceptions of COVID-19}

There are over half (55\%) of respondents agreed that COVID-19 can cause death, although $19 \%$ who disagreed with this statement. Regarding the statement about all ages being affected by COVID-19, 52\% agreed with the statement. Similarly, 52\% agreed that COVID-19 could be prevented through regular, nutritious eating and $56 \%$ agreed that a weak immune systems left people more susceptible to contracting COVID-19, although $11 \%$ answered they do not know. There are $34 \%$ respondents said it was quite possible to transmit COVID-19 through activities outside the home, and $11 \%$ of respondents thought this was 
impossible. Further, $40 \%$ of respondents said it was very possible to contract COVID-19 if they did not use a mask when leaving the house, although $4 \%$ respondents said this was impossible. On the other hand, $45 \%$ of respondents felt they could control the risk of transmitting COVID-19. Table 6 shows that an overview of risk perceptions against COVID-19.

Table 5. Frequency distribution based on attitudes toward COVID-19

\begin{tabular}{lc}
\hline \multicolumn{1}{c}{ Questions } & $(\%)$ \\
\hline What is the severity of COVID-19? & 2 \\
Not bad & 15 \\
A little bad & 47 \\
Severe & 36 \\
Awfully & \\
In your opinion, how serious is the risk of COVID-19? & 10 \\
A little serious & 45 \\
Seriously & 45 \\
Very serious & \\
Are you ready to face the risk of spreading COVID-19? & 15 \\
Very unprepared & 16 \\
Not ready & 45 \\
Ready & 24 \\
Very ready & \\
Are you afraid of the risk of contracting COVID-19? & 6 \\
Very afraid & 24 \\
Not afraid & 36 \\
Afraid & 34 \\
Very afraid & \\
&
\end{tabular}

Table 6. Frequency distribution based on perceptions of risk for COVID-19

\begin{tabular}{|c|c|c|c|c|c|}
\hline \multirow[b]{2}{*}{ Questions } & \multicolumn{5}{|c|}{ Answer (\%) } \\
\hline & $\begin{array}{l}\text { Strongly } \\
\text { disagree }\end{array}$ & Disagree & Do not know & Agree & $\begin{array}{c}\text { Strongly } \\
\text { agree }\end{array}$ \\
\hline \multicolumn{6}{|c|}{$\begin{array}{ll}\text { Perceptions of risk against COVID-19 } & \\
\end{array}$} \\
\hline $\begin{array}{l}\text { Every case of COVID has the potential to cause } \\
\text { death }\end{array}$ & 9 & 19 & 5 & 55 & 12 \\
\hline People of all ages can catch COVID & 5 & 6 & 11 & 52 & 26 \\
\hline $\begin{array}{l}\text { I believe that eating regularly, nutritionally and } \\
\text { a healthy lifestyle will prevent contracting } \\
\text { COVID }\end{array}$ & 6 & 9 & 10 & 52 & 23 \\
\hline Only people with weak immune systems can & 6 & 7 & 11 & 56 & 20 \\
\hline & Very likely & $\begin{array}{l}\text { Quite } \\
\text { possibly }\end{array}$ & $\begin{array}{l}\text { Somewhat } \\
\text { maybe }\end{array}$ & Impossible & \\
\hline \multicolumn{6}{|l|}{$\begin{array}{l}\text { Risk of transmission of COVID-19 outside } \\
\text { the home and ability to control the risk of } \\
\text { transmission of COVID-19 }\end{array}$} \\
\hline $\begin{array}{l}\text { If you continue to do activities outside the } \\
\text { home, what are your chances of contracting } \\
\text { COVID-19? }\end{array}$ & 26 & 34 & 29 & 11 & \\
\hline \multirow[t]{2}{*}{$\begin{array}{l}\text { If you leave the house and do not use a mask } \\
\text { covering your nose and mouth, what are your } \\
\text { chances of catching COVID? }\end{array}$} & 40 & 35 & 21 & 4 & \\
\hline & Very capable & $\begin{array}{l}\text { Enough } \\
\text { capable }\end{array}$ & Able & Not capable & \\
\hline $\begin{array}{l}\text { Are you able to control your risk so you do } \\
\text { not catch COVID? }\end{array}$ & 16 & 45 & 27 & 12 & \\
\hline
\end{tabular}

\subsection{Perceptions of prevention of COVID-19 transmission by health protocols}

The results reported in Table 7 regarding the perception of trust in the application of handwashing and hand sanitizer in preventing the transmission of COVID-19 show that almost all respondents (96\%) believe that washing hands and using hand sanitizer prevents the transmission of COVID-19, although 4\% said they did not believe in this method. Almost all (98\%) respondents stated they would wash their hands with soap and use hand sanitizer to prevent the transmission of COVID-19 because COVID-19 is very serious, washing their hands was easy, they are following government directives, and they feel responsible for their health and believe washing hands is helpful. 
Table 7. Characteristics of respondents based on perceptions of prevention of COVID-19 transmission Question

Perceptions Regarding Belief in the Application of Hand Washing and Hand Sanitizer in Preventing the
Transmission of COVID-19

Do you believe that washing hands with soap can prevent transmission?

Do you believe that hand sanitizers can prevent transmission?

Will you wash your hands with soap and hand sanitizer to prevent the spread of COVID-19?

Wash your hands with soap

Wash your hands with a hand sanitizer

Yes $\quad$ No

$(\%)$ $(\%)$

Reasons n=94 (\%)

1-2 reasons

COVID-19 is very serious

Take responsibility for your health

COVID-19 is very serious, Easy access to handwashing facilities

Responsible for your health, Believe that handwashing helps a lot

$\geq 3$ reasons

COVID-19 is very serious, Easy access to handwashing facilities, Believe that washing hands is very helpful, Doing under the direction of the government

COVID-19 is very serious, Easy access to handwashing facilities, Responsible for your health

All reasons

Perceptions of Physical Distancing in Prevention of COVID-19 Transmission

Do you believe that maintaining a minimum physical distance of 1.5 meters can prevent transmission of COVID-19?

Will you maintain a physical distance of at least 1.5 meters to prevent transmission of COVID?

Do you still feel worried even though you have followed the recommendation to keep your distance, not leave the

house/hang out with friends?

$\begin{array}{ll}96 & 4 \\ 96 & 4 \\ 94 & 6 \\ 98 & 2 \\ 96 & 4\end{array}$

Reason $\mathrm{n}=89(\%)$

1-2 reasons

COVID-19 is very serious

Take responsibility for your health

Often sick, COVID-19 is very serious, Responsible for your health

COVID-19 is very serious, take responsibility for your health

$\geq 3$ reasons

COVID-19 is very serious, Responsible for your health, Risk of contracting COVID-19

COVID-19 is very serious, Regret not doing this, Other people are doing the same thing,

COVID-19 is very serious, Regret not doing this, At the direction of the government,

COVID-19 is very serious, Responsible for your health, Risk of contracting COVID-19, Preventing transmission of

COVID-19 to people around you

All reasons

Perceptions of wearing masks and staying at home

Do you believe that staying at home can reduce the risk of catching COVID-19?

Do you believe that using a mask when sick or when leaving the house can prevent the transmission of COVID-19?

3

4

13

4

7

14

49

91

The chances of getting covid are the same whether you use a mask or not

Strongly Disagree

Disagree

Do not know

Agree

Strongly agree

Reasons for using masks

1-2 reasons

COVID-19 is very serious

Have a mask

COVID-19 is very serious, Have a mask, Often Sick,

Take responsibility for your health

Take responsibility for your health, Prevent transmission of COVID-19 to the people around you,

COVID-19 is very serious, take responsibility for your health

COVID-19 is very serious, Responsible for your health, Risk of contracting COVID-19, Prevent transmission of

COVID-19 to people around you,

All reasons

Almost all online motorcycle taxi drivers (91\%) believe that maintaining a minimum distance of 1.5 meters can prevent the transmission of COVID-19; however, although $89 \%$ of respondents said they have implemented physical distancing, $87 \%$ stated they still feel worried, and $11 \%$ stated they have not implemented these precautions at all. Respondents stated they maintain a physical distance due to frequent illness; they take COVID-19 very seriously, feel responsible for their health (16\%), and want to prevent the transmission of COVID-19 to those around them (10\%).

Online motorcycle taxi drivers $(91 \%)$ believe that staying at home can reduce the risk of contracting COVID-19. Almost all respondents believe that using a mask when sick and when leaving the house can prevent contracting COVID-19 and almost half disagreed or strongly disagreed with the statement that people 
have the same chance of contracting COVID-19 regardless of whether they wear a mask. Respondents stated they use masks because they think COVID-19 is a very serious problem, respondents are often sick and they have masks (27\%), and they feel responsible for their health and preventing the transmission of COVID-19 to others $(6 \%)$. The depiction of perceptions about believing in applying hand washing and using hand sanitizers in preventing transmission of COVID-19 is presented a shown in Table 7.

\subsection{Relationship between knowledge and attitudes, perceptions of risk transmission of COVID-19 and perceptions of COVID-19 prevention: Bivariate analysis}

The results of the bivariate analysis showed that respondents' knowledge of COVID-19 was related to attitudes $(p=0.000)$ and perceptions $(p=0.018)$ of the risk of transmitting COVID-19 but not related to perceptions of COVID-19 prevention $(\mathrm{p}=0.116)$. The results of the bivariate analysis using the Spearman rank test are presented in Table 8.

Table 8. Results of the analysis of the relationship between knowledge and attitudes, perceptions of risk transmission of COVID-19 and perceptions of COVID-19 prevention

\begin{tabular}{|c|c|c|c|c|c|}
\hline \multicolumn{6}{|l|}{ Correlations } \\
\hline & & & Attitude & $\begin{array}{l}\text { Perception of transmission } \\
\text { risk }\end{array}$ & $\begin{array}{l}\text { Perception of transmission } \\
\text { prevention }\end{array}$ \\
\hline \multirow{3}{*}{ Spearman's rho } & \multirow{3}{*}{ Knowledge } & $\begin{array}{l}\text { Correlation } \\
\text { coefficient }\end{array}$ & $.350^{* *}$ & $.236^{*}$ & .158 \\
\hline & & Sig. (2-tailed) & .000 & .018 & .116 \\
\hline & & $\mathrm{n}$ & 100 & 100 & 100 \\
\hline
\end{tabular}

**. Correlation is significant at the 0.01 level (2-tailed).

*. Correlation is significant at the 0.05 level (2-tailed).

\subsection{Discussion}

COVID-19 is a new and highly contagious disease, so adherence to health protocols to maintain personal and public health is dependent on public knowledge and perceptions of the virus. By identifying knowledge, perceptions, and attitudes we hoped to provide information for intervention programs that can help prevent the spread of COVID-19. The results of this study indicate that $75 \%$ of respondents feel they have sufficient knowledge about COVID-19. Most of the respondents stated that COVID-19 is very contagious, but some stated that COVID-19 is not contagious and takes months to spread. This level of knowledge is related to access to information on sources commonly accessed by respondents, namely online news, social media, television, and information from other people. This is in accordance with previous research that social media, such as Instagram (83.7\%) and Whatsapp group (73.7\%) contributed significantly to the delivery of information about COVID-19 [14]. Audience efforts to select and remove hoaxes and false rumors regarding COVID-19 are important, and only plausible scientific information is allowed to raise awareness among the general public [15]. Okan et al. found the most effective source of information regarding COVID-19 for groups of people with high daily mobilization and activities was through digital media [16]. According to Basch et al. digital media can increase audience interest and awareness through digital telephones equipped with attractive pictures, colors, and messages, for example, the use of short videos [17].

Respondents also knew how to reduce the risk of transmission and the transmission mechanism of COVID-19, namely by washing hands, using masks, maintaining distance, staying at home, exercising regularly, and consuming nutritious foods. Similarly, Okan et al. highlighted COVID-19 prevention behaviors that can be implemented effectively, such as increasing endurance and always practicing selfprotection and vigilance by maintaining distance and always washing one's hands [16]. This result is in line with our results, namely that almost half of the total respondents stated that COVID-19 is transmitted through droplets and contaminated surfaces and it was important to wash their hands using soap and running water. One of the determinants that also affects the behavioral pattern of preventing the transmission of COVID-19 is the knowledge or level of public literacy in receiving and transferring correct information about COVID19 [15], [18], explained that $96.7 \%$ of informal workers in Bangladesh thought COVID-19 was very dangerous and $48.3 \%$ had accurate knowledge about this infectious disease. Alsan et al. explained that people from middle and lower economic groups tend to have less knowledge about COVID-19 than people from middle- and upper-class groups, who show a higher sensitivity to and need for information regarding efforts to prevent COVID-19 transmission [19]. 


\subsubsection{Knowledge with attitude towards COVID-19}

The findings of this study indicate that knowledge is related to respondents' positive attitudes towards COVID-19, whereby the higher their knowledge score, the higher their attitudes score towards COVID-19. In previous research, a higher COVID-19 knowledge score was found to be significantly associated with a lower likelihood of negative attitudes and potentially dangerous practices towards the COVID-19 epidemic [20]. Peng et al. also found that good knowledge of COVID-19 demonstrated a positive attitude and proactive practice during the COVID-19 outbreak [10]. This corresponds with the results of this study, as respondents had a positive attitude about COVID-19, stating that COVID-19 was a very severe disease and the risk of transmission was serious. Moreover, although they also stated they were ready to face the risk of transmitting COVID-19, respondents stated they were very afraid because they perceived COVID19 can cause death and can affect all ages. This is in accordance with previous research that public fear and concern about COVID-19 is because it can cause death and there is no treatment for coronavirus [18]. Respondents also stated that they did not know that a weak level of immunity facilitates the transmission of COVID-19. According to [21] people who have low knowledge or negative attitudes towards a disease tend to be more afraid and panicked in the face of a pandemic.

In other hands, the high confidence and positive attitudes of society can be an alternative used by institutions that cover workers and the government in a prompt response to taking stringent control and precautionary measures against COVID-19 [7]. This previous study is in accordance with the results of this study that as many as $45 \%$ of respondents are confident and will face the risk of spreading COVID-19. A public health campaign strategy with an approach to values and attitudes to life in workers to should be conducted to help in controlling the spread of the disease in this group, especially in work activities [22].

\subsubsection{Knowledge with perceptions of the risk of COVID-19 transmission}

We also found knowledge was related to the perception of the risk of transmission of COVID-19. There are still respondents $(11 \%)$ who have a poor perception of the risk of transmitting COVID-19. Some respondents stated that COVID-19 cannot occur outside the home, and although $40 \%$ of respondents believed they could contract COVID-19 if they do not use a mask when leaving the house, $4 \%$ believed it was impossible to get infected. This shows that online motorcycle taxi drivers still have a low risk perception of COVID-19 and this will certainly be dangerous for themselves and other individuals they may come into contact with. Inadequate knowledge of disease transmission and adherence to stay-at-home protocols due to perceived low risk can put the person and others at risk. Their perceptions and behaviors can have a major impact on the spread of a pandemic [10]. Perceptions of low risk were found among those with low knowledge of transmission, indicating that correct and adequate knowledge is the key to keeping themselves and others safe. Accordingly, community non-pharmaceutical health measures are being promoted to reduce the risk and impact of epidemics and pandemics [23].

Several research results have also stated that low perceptions of risk and knowledge regarding transmission of COVID-19 will also have an impact on anxiety from the community itself. The increasing anxiety about the speed of transmission of COVID-19 will also affect the actions taken in self-protection efforts [24]. In line with previous research that some super-spreaders of unintentionally transmit the coronaviruses because of their mobilization and hyperactivity in outside the building [25]. The delivery of health risk communication messages therefore tend to be more effective when includes information about the level of risk and effectiveness of health behavior designed to protect the workers from COVID-19 at both a personal or societal level [13].

\subsubsection{Knowledge with perceptions of prevention of COVID-19 transmission}

This study found no relationship between knowledge and perceptions of preventing the transmission of COVID-19. In the study conducted by Ifroh and Asrianti perception influenced behavioral decisions to prevent COVID-19, especially in young adults or active groups [14]. According to research by Kuang et al. [26], [27] the perception of risk that is felt by the community has greater implications for widespread fear and can cause mental stress and excessive anxiety. The feelings of anxiety and fear that arise can influence a person to act, especially on COVID-19 prevention behavior. In certain psychological situations the knowledge level factor cannot help to relieve the anxiety felt by society [27].

Another study conducted by Basch et al. [28] found threat perception refers to personal beliefs about the possibility of contracting this virus, which includes two subcomponents, perceived vulnerability (the degree to which a person feels vulnerable to an illness) and perceived severity (beliefs about how the seriousness of the consequences of the condition). The health belief model describes that a person's belief is stronger in the severity of disease and the more vulnerable they feel, the stronger they will be motivated to avoid it, where knowledge and literacy factors are not the main determinants [29]. Based on this model, the 
results of this study assess that efforts to increase community beliefs about COVID-19 and strengthen the desired behavior must consider multicultural social methods and approaches [30].

Prevention of COVID-19 transmission is through the implementation of health protocols, which include washing hands with soap and using hand sanitizer, physical distancing, using masks, and staying at home. In line with previous research, the challenges in implementing community distancing are communication and social interaction factors; in other words, the closer the kinship is built in a group, the more difficult it will be to maintain physical distance [31]. This is of course closely related to the type of work of the respondent who always interacts with other people both when delivering other people and when delivering orders to consumers. Leung $e t a l$. [32] found that although the use of masks is one of the effective efforts to avoid the spread of COVID-19, one of the obstacles to getting people to regularly wear mask is due to discomfort. Scott et al. [33] explained that in addition to public awareness in using masks, there needs to be an intervention in the form of regulations and policies both institutionally and by the government to implement strict protocols for wearing masks. Similar policies are needed for online motorcycle taxi drivers from institutions that overshadow them, as they need to be more committed to increasing worker discipline to use masks properly.

Our results support research conducted by Ferdous et al. [18] as well as Rollston and Galea [30]. They found knowledge, attitudes, and perceptions regarding COVID-19 correlate with each other in the longterm behavior formation process, especially in efforts to prevent COVID-19, both at the individual or community level. Research conducted by Lee and You [34] also found that knowledge and attitudes in supporting the COVID-19 prevention program at the community group level are one of the determining factors for the success of implementing massive COVID-19 prevention with a higher success rate compared to groups who have low knowledge of COVID-19. Indeed, more comprehensive health education efforts for groups of online motorcycle taxi riders can further increase knowledge, attitudes, and internal perceptions so that the implementation and culture of behavior to prevent the transmission of COVID-19 can be applied in a disciplined manner by this population.

\subsubsection{Limitations}

The sampling in this study was carried out through the WhatsApp social media platform. As a result, there is the possibility of bias because some drivers may not have been informed or given the chance to participate in our study. Self-selection bias may have occurred because respondents who completed the questionnaire and were examined might not represent cases that exist in the community. After all, there could be differences between the groups that participated and those who refused. Moreover, there is a limit to the representativeness of our findings to the entire population of online motorcycle taxi drivers. More systematic and inclusive sampling methods are needed to increase the representativeness and generalizability of findings. A further limitation of this study is the possibility of participants giving positive attitude responses based on what they feel is expected of them.

\section{CONCLUSION}

Majority, online motorcycle taxi drivers have sufficient knowledge about COVID-19, but some drivers still have limited or no knowledge about COVID-19. Some online motorcycle taxi drivers have important misconceptions about COVID-19, namely that COVID-19 is not contagious, they do not know that weak immune resistance causes them to contract COVID-19, and it is highly unlikely that they will contract COVID-19 when leaving the house without wearing a mask. Correcting these misunderstandings should be targeted when developing interventions to online motorcycle taxi drivers. Our findings show the importance of increasing health education and literacy among online motorcycle taxi drivers regarding the urgency of preventing COVID-19 through interpersonal approaches and conventional as well as digital-based groups to improve their attitudes and practices towards COVID-19.

\section{ACKNOWLEDGEMENTS}

This study was funded by the Islamic Development Bank (IsDB), Development of Four Higher Education Institution, Project Implementation Unit of the Mulawarman University of Indonesia in Research Center of Medicine and Cosmetic from Tropical Rainforest Resources (grant numbers: 303/UN.17.11/PL/2020). We also thank to Application of Karya Anak Bangsa Indonesia Company, East Kalimantan Branch, and the enumerators Hasmawati, Agus Wiranto, Ahmad Dzikri, M. Fajar Siddiq, Abdul Aziz. 


\section{REFERENCES}

[1] World Health Organization, "Rolling updates on coronavirus disease (COVID-19)," World Health Organization, 2020. [Online]. Available: https://www.who.int/emergencies/diseases/novel-coronavirus-2019/events-as-theyhappen

[2] S. COVID-19, "https://covid19.go.id/," Satgas COVID-19, 2020. [Online]. Available: https://covid19.go.id/

[3] "Press Release - COVID-19 di Kalimantan Timur," Satgas Cocid-19 Kalimantan Timur, 2020. [Online]. Available: https://covid19.kaltimprov.go.id/press-release

[4] A. F. RR Ukirsari Manggalani, "COVID-19 Pandemic Storm, Ojol Business Affected Until Now (In Inonesia: Badai Pandemi COVID-19, Bisnis Ojol Terdampak Hingga Kini)," Search Login Kirim Artikel Yoursay, 2020. [Online]. Available: https://www.suara.com/otomotif/2020/05/20/094000/badai-pandemi-covid-19-bisnis-ojolterdampak-hingga-kini?page $=$ all

[5] M. S. F.Maulana Shidiqi, D. L. Setyowati, "Knowledge and Attitude Relationships with Behaviors To Prevention of Coronavirus Disease Transmission 2019 (COVID-19) on A Two Wheel Online Ojek Driver in Samarinda City," Thesis, Mulawarman University, Indonesia, 2020.

[6] D. M. Bell et al., "Public health interventions and SARS spread, 2003," Emerg. Infect. Dis., vol. 10, no. 11, pp. 1900-1906, 2004, doi: 10.3201/eid1011.040729.

[7] M. K. Al-hanawi, "Knowledge , Attitude and Practice Toward COVID-19 Among the Public in the Kingdom of Saudi Arabia : A Cross-Sectional Study," vol. 8, no. May, pp. 1-10, 2020, doi: 10.3389/fpubh.2020.00217.

[8] J. Prasad Singh, A. Sewda, and D. G. Shiv, "Assessing the Knowledge, Attitude and Practices of Students Regarding the COVID-19 Pandemic," J. Health Manag., vol. 22, no. 2, pp. 281-290, 2020, doi: $10.1177 / 0972063420935669$.

[9] S. Maheshwari, P. Gupta, R. Sinha, and P. Rawat, "Knowledge, attitude, and practice towards coronavirus disease 2019 (COVID-19) among medical students: A cross-sectional study," J. Acute Dis., vol. 9, no. 3, 2020, doi: 10.4103/2221-6189.283886.

[10] Y. Peng et al., "A cross-sectional survey of knowledge, attitude and practice associated with COVID-19 among undergraduate students in China," BMC Public Health, vol. 20, no. 1, pp. 1-13, 2020, doi: 10.1186/s12889-02009392-z.

[11] D. Roy, S. Tripathy, S. Kumar, and N. Sharma, "Since January 2020 Elsevier has created a COVID-19 resource centre with free information in English and Mandarin on the novel coronavirus COVID-19. The COVID-19 resource centre is hosted on Elsevier Connect, the company's public news and information," Asian J. Psychiatry J., vol. 51, no. January, 2020.

[12] N. T. Brewer, G. B. Chapman, F. X. Gibbons, M. Gerrard, K. D. McCaul, and N. D. Weinstein, "Meta-analysis of the relationship between risk perception and health behavior: The example of vaccination," Heal. Psychol., vol. 26, no. 2, pp. 136-145, 2007, doi: 10.1037/0278-6133.26.2.136.

[13] S. Dryhurst et al., "Risk perceptions of COVID-19 around the world," J. Risk Res., vol. 23, no. 7-8, pp. 994-1006, 2020, doi: 10.1080/13669877.2020.1758193.

[14] T. A. Riza Hayati Ifroh and Tanti asrianti, "Health Literacy, Media Exposure and Behavior Among Young Adults During the COVID-19 Pandemic," J. Ilmu Kesehat. Masy., vol. 11, no. 3, pp. 223-236, 2020, doi: 10.26553/jikm.2020.11.3.223-235

[15] S. Tasnim, M. Hossain, and H. Mazumder, "Impact of Rumors and Misinformation on COVID-19 in Social Media," J. Prev. Med. Public Health vol. 53, no. 3, pp. 171-174, 2020, doi: 10.3961/jpmph.20.094.

[16] O. Okan, T. M. Bollweg, E. M. Berens, K. Hurrelmann, U. Bauer, and D. Schaeffer, "Coronavirus-related health literacy: A cross-sectional study in adults during the COVID-19 infodemic in Germany," Int. J. Environ. Res. Public Health, vol. 17, no. 15, pp. 1-20, 2020, doi: 10.3390/ijerph17155503.

[17] C. H. Basch, G. Clarke, Z. M.- Erwin, J. Mohlman, A. Cosgrove, and N. Quinones, "ScienceDirect News coverage of the COVID-19 pandemic: Missed opportunities to promote health sustaining behaviors," Infect. Dis. Heal., vol. 25, no. 3, pp. 205-209, 2020, doi: 10.1016/j.idh.2020.05.001.

[18] M. Z. Ferdous, M. S. Islam, M. T. Sikder, A. S. M. Mosaddek, J. A. Zegarra-Valdivia, and D. Gozal, "Knowledge, attitude, and practice regarding COVID-19 outbreak in Bangladesh: An onlinebased cross-sectional study," PLoS One, vol. 15, no. 10 October, pp. 1-17, 2020, doi: 10.1371/journal.pone.0239254.

[19] M. Alsan, S. Stantcheva, D. Yang, and D. Cutler, "Disparities in Coronavirus 2019 Reported Incidence, Knowledge, and Behavior Among US Adults," JAMA Netw. open, vol. 3, no. 6, 2020, doi: 10.1001/jamanetworkopen.2020.12403.

[20] B. L. Zhong et al., "Knowledge, attitudes, and practices towards COVID-19 among chinese residents during the rapid rise period of the COVID-19 outbreak: A quick online cross-sectional survey," Int. J. Biol. Sci., vol. 16, no. 10, pp. 1745-1752, 2020, doi: 10.7150/ijbs.45221.

[21] H. C. Nguyen et al., "People with Suspected COVID-19 Symptoms Were More Likely Depressed and Had Lower Health-Related Quality of Life: The Potential Benefit of Health Literacy," J. Clin. Med., vol. 9, no. 4, p. 965, 2020, doi: $10.3390 / \mathrm{jcm} 9040965$.

[22] R. K. Sinuraya, R. Abdulah, and H. Koyama, "Knowledge, Attitude, and Practice During the COVID-19 Pandemic : A Review," J. Multidiscip. Healthc., vol. 13, no. March, pp. 727-733, 2020.

[23] WHO, Non-pharmaceutical public health measures for mitigating the risk and impact of epidemic and pandemic influenza. A checklist for pandemic influenza risk and impact management: building capacity for pandemic response. World Health Organization, 2019.

[24] G. Psychiatry et al., "Perception of and anxiety about COVID-19 infection and risk behaviors for spreading infection : an international comparison," Ann. Gen. Psychiatry, pp. 1-11, 2021, doi: 10.1186/s12991-021-00334-6. 
[25] Y. kai Li et al., "Clinical and Transmission Characteristics of COVID-19 - A Retrospective Study of 25 Cases from a Single Thoracic Surgery Department," Curr. Med. Sci., vol. 40, no. 2, pp. 295-300, 2020, doi: 10.1007/s11596-020-2176-2.

[26] J. Kuang, S. Ashraf, U. Das, and C. Bicchieri, "Awareness, risk perception, and stress during the COVID-19 pandemic in communities of Tamil Nadu, India," Int. J. Environ. Res. Public Health, vol. 17, no. 19, pp. 1-12, 2020, doi: 10.3390/ijerph17197177.

[27] T. Medicine, "The pandemic of social media panic travels faster than the COVID-19 outbreak," J. ofTravel Med., vol. 1, no. March, pp. 1-2, 2020, doi: 10.1093/jtm/taaa031.

[28] A. C. Q. Corey H. Basch, Grace Clarke Hillyer, Zoe Meleo- Erwin, Jan Mohlman, "News coverage of the COVID19 pandemic: Missed opportunities to promote health sustaining behaviors," Infect. Dis. Heal., vol. 25, pp. 205209, 2020.

[29] Government Communication Network, Communications and behaviour change. COI Publications, 2009.

[30] R. Rollston and S. Galea, "COVID-19 and the Social Determinants of Health," Am. J. Heal. Promot., vol. 34, no. 6, pp. 687-689, 2020, doi: 10.1177/0890117120930536b.

[31] F. Syadidurrahmah, F. Muntahaya, S. Z. Islamiyah, and T. A. Fitriani, "Physical Distancing Behavior of Students of UIN Syarif Hidayatullah Jakarta during the COVID-19 Pandemic Physical Distancing Behavior of Students of UIN Syarif Hidayatullah Jakarta during the COVID-19 Pandemic (In Indonesia: Perilaku Physical Distancing Mahasiswa UIN Syarif Hidayatullah Jakarta pada Masa Pandemi COVID-19 Physical Distancing Behavior of Students of UIN Syarif Hidayatullah Jakarta dur- ing COVID-19 Pandemic," Indones. J. Heal. Promot. Behav., vol. 2, no. 1, pp. 29-37, 2020.

[32] C. C. Leung, k. K. Cheng, T. H. Lam, and G. B. Migliori, "Mask wearing to complement social distancing and save lives during COVID-19," Int. J. Tuberc. Lung Dis., vol. 24, no. 6, pp. 556-558, 2020, doi: 10.5588/ijtld.20.0244.

[33] N. Scott et al., "Cases in a major metropolitan city," SSRN Electron. J., vol. 1, no. 1, 2019, doi: http://dx.doi.org/10.2139/ssrn.3714648.

[34] M. Lee and M. You, "Psychological and behavioral responses in South Korea during the early stages of coronavirus disease 2019 (COVID-19)," Int. J. Environ. Res. Public Health, vol. 17, no. 9, 2020, doi: 10.3390/ijerph17092977. 